\title{
Peluang dan Tantangan Initial Public Offering (IPO) Pada Perusahaan Start-Up di Indonesia
}

\author{
Anggi Purnama Harahap \\ Universitas Islam Negeri Sulthan Thaha Saifuddin \\ anggipurnama.sh.mh@gmail.com \\ Rahmad Ramadhan Hasibuan \\ Universitas Indonesia \\ rahmadramadhanhsb@gmail.com \\ Lupitta Risma Candanni \\ Universitas Indonesia \\ glupitarismacendani@yahoo.co.id
}

\begin{abstract}
This paper will discuss the initial public offering (IPO) for startup companies. Case study of PT Aplikasi Karya Anak Bangsa Go-Jek. The discussion in this paper will emphasize startups and their comparison with IPOs in ordinary companies (Case Study PT Jasa Armada Indonesia, Tbk) and other startup companies, namely PT Kioson Commercial Indonesia, Tbk) in 2017. Qualitative approach with normative descriptive and benchmark method are used to analyze the problem mention above. This research finds that in general, public regulations and general guidance in Law Number 8 of 1995 concerning the Capital Market and other related regulations sufficient to meet the requirements of going public for public companies. But with the development of startup companies in Indonesia, especially PT Aplikasi Karya Anak Bangsa (Go-Jek), planning to conduct an initial public offering encourages the government to immediately make decisions on the initial public offering process rules so that these arrangements will not only reach ordinary companies with the number of assets large, but also able to reach start-up companies to contribute to the development of the national economy.
\end{abstract}

Keywords: Initial Public Offering, Startup Company, Capital Market.

\section{PENDAHULUAN}

Pendanaan perusahaan dari dalam pada umumnya menggunakan laba ditahan yang dihimpun sedemikian rupa sehingga dapat menambah modal usaha perusahaan tersebut. Sementara pendanaan dari luar perusahaan dapat berupa pinjaman kepada pihak ketiga/hutang, maupun penyertaan dalam bentuk saham. Salah satu alternatif pendanaan dari luar perusahaan yang dirasa cukup baik dalam meningkatkan skala perusahaan adalah dengan mekanisme penyertaan modal melalui proses go public atau penawaran umum perdana (Initial Public Offering). Langkah 
melakukan IPO bagi perusahaan startup bukanlah sesuatu yang mudah apalagi dengan berbagai macam peraturan dan mekanisme yang disyaratkan untuk melakukan go public.

Sebelumnya, mengenai ketentuan untuk melakukan go public sendiri diatur dalam Pasal 1 angka 15 Undang-Undang Nomor 8 Tahun 1995 tentang Pasar Modal (UUPM) yang menjelaskan bahwa IPO adalah kegiatan penawaran efek yang dilakukan oleh emiten untuk menjual efek kepada masyarakat yang diatur dalam tata cara yang diatur dalam undang-undang ini dan aturan pelaksanaannya. Hal yang sama juga dikemukakan oleh Hartono dan Ali (2017) yang mengemukakan bahwa IPO merupakan penawaran saham di pasar perdana yang dilakukan perusahaan yang hendak go public. Dari pengertian go public tersebut diatas maka terlihat bahwa go public merupakan salah satu alternatif cara yang dapat digunakan oleh suatu perusahaan dengan keterbatasan dana untuk dapat mengembangkan perusahaannya.

Berdasarkan Pasal 1 angka 8 Undang-Undang Nomor 40 Tahun 2007 tentang Perseroan Terbatas (UUPT), Perseroan Publik adalah perseroan yang memenuhi kriteria jumlah pemegang saham dan modal disetor sesuai dengan ketentuan dengan ketentuan peraturan perundangundangan di Pasar Modal. Sementara itu untuk menjadi perusahaan terbuka, UUPM mengatur bahwa suatu perseroan terbatas harus dimiliki oleh sekurang-kurangnya 300 pemegang saham dan memiliki modal disetor sekurang-kurangnya Rp.3.000.000.000,- atau suatu jumlah pemegang saham dan modal yang disetor yang ditetapkan dengan peraturan pemerintah.

Pada dasarnya, perusahaan kecil/startup atau perusahaan tertutup yang baru berdiri tentu akan mulai mempertimbangkan untuk mengikutsertakan perusahaannya dalam pasar modal. Meskipun demikian, faktanya saat ini, perusahaan yang akan mempertimbangkan untuk melakukan penawaran umum perdana (IPO) lebih terganggu dengan berbagai persyaratan mengenai perkembangan pendapatan dan laba perusahaan dibanding memperhatikan apa saja persyaratan formal yang diatur oleh hukum (peraturan perundang-undangan). Hal ini pun tidak hanya terjadi di Indonesia, Arthur H. Bill (1993) menyatakan IPO di Amerika Serikat yang terjadi adalah bahwa: The small, private company that's on the rise may someday want to consider going public through an initial public offering of its common stock. Right now, however, it's understandably more concerned about revenue and profit than it is about the legal requirements for a possible, but uncertain, IPO in its future.

Untuk menjadi perusahaan terbuka, setiap calon emiten harus sudah memenuhi setiap syarat dan ketentuan mengenai jumlah minimal kepemilikkan saham serta jumlah minimal modal disetor. Selanjutnya adalah setelah perusahaan berhasil mengubah anggaran dasarnya maka ia 
dapat melakukan apa yang disebut dengan proses go public atau IPO untuk kemudian perusahaan tersebut menjadi suatu perusahaan terbuka.

Saat ini, belum banyak perusahaan-perusahaan rintisan (startup) di Indonesia yang sudah melakukan listing di Bursa Efek dan menjadikan perusahaannya sebagai perusahaan terbuka. Selain karena perkembangan perusahaan-perusahaan rintisan (startup) yang sebelumnya tidak mendapat perhatian lebih dari khalayak umum, proses dan tahapan penawaran umum perdana yang cukup rumit - bahkan untuk perusahaan besar sekalipun-membuat mekanisme IPO belum banyak dilirik oleh perusahaan rintisan (startup) di Indonesia. Adanya ketertarikan PT Aplikasi Karya Anak Bangsa (Go-Jek) untuk melakukan penawaran umum perdana pada akhirnya membawa penulis untuk dapat mendalami lebih lanjut mengenai proses IPO secara umum, bagaimana pengaturannya, serta apa saja kendala dan hambatan yang dihadapi perusahaan rintisan (startup) dalam melakukan penawaran umum perdana di Indonesia.

\section{KAJIAN LITERATUR}

\section{Initial Public Offering}

Penawaran Umum Perdana atau Initial Public Offering (IPO) adalah bentuk upaya perusahaan untuk menjadi perusahaan terbuka. Sebagai pengantar, penulis akan mencoba mengulas kembali secara singkat mengenai mekanisme penawaran umum perdana ini. Penawaran umum perdana atau initial public offering (IPO) adalah the first time that shares in a company are sold to public investors and subsequently traded on the stock market (Draho, Jason. (2004) (pertama kalinya saham-saham dalam suatu perusahaan dijual kepada para investor umum dan untuk kemudian diperdagangkan dalam pasar saham).

Dalam penggunaannya seringkali istilah penawaran umum perdana (IPO) disamakan maknanya dengan istilah go public. Istilah go public sendiri sebenarnya mempunyai arti perusahaan menjual saham biasa atau saham preferen, atau obligasi yang merupakan modal perusahaan (ekuitas dan utang jangka panjang) untuk "pertama kalinya" kepada masyarakat luas (Widioatmojo, Sawidji. 2015). IPO atau penawaran umum perdana hanya terjadi satu kali dalam perjalanan sejarah perusahaan yang melakukan go public, sedangkan go public bisa dilakukan berkali-kali. Misalnya, setelah satu tahun emiten go public dengan IPO, emiten kembali menjual saham dalam bentuk right issue. Kemudian, setelah berjalan dua tahun, emiten kembali go public dengan menerbitkan obligasi.

Selanjutnya, perusahaan yang melakukan go public itu disebut perusahaan publik. Perusahaan publik ada yang dikategorikan tercatat 
dan ada yang tidak tercatat. Perusahaan publik yang tercatat adalah yang sahamnya dicatatkan di bursa efek, sedangkan perusahaan publik yang tidak tercatat adalah perusahaan yang meskipun menjual sahamnya kepada masyarakat luas, tetapi tidak dicatatkan di bursa efek. Contohnya saham PT Abdi Bangsa, yang dijual kepada masyarakat luas guna membiayai pembangunan pesawat CN 250.

Bagi perusahaan, menjual saham kepada masyarakat berarti mendapat pilihan lain dalam mendapatkan modal, guna meningkatkan omset perusahaan. Sebagaimana diketahui, modal perusahaan digolongkan dalam 2 (dua) jenis, yaitu utang dan ekuitas. Bila go public, permodalan perusahaan hanya bersumber dari perbankan, yaitu dari kredit. Karena bunga kredit harus selalu dibayar oleh perusahaan secara rutin (tidak bisa ditunda), dan seringkali suku bunga kredit sangat tinggi, berarti perusahaan mendapat modal dengan biaya yang mahal. Sebaliknya modal bisa saja disediakan dari kantong pribadi, tapi jumlahnya akan terbatas. Selain itu bila diteruskan sampai generasi selanjutnya, besar kemungkinannya perusahaan akan hancur akibat persoalan pewarisan. Jika go public maka perusahaan bisa memobilisasi dana tanpa batas dari masyarakat, dan perusahaan akan dikelola secara professional sehingga akan bertahan dalam jangka waktu sangat lama, seperti halnya perusahaan-perusahaan besar kaliber dunia yang sekarang kita kenal seperti Coca-cola, Johnson \& Johnson, Microsoft, IBM, Toyota, Toshiba, Bayer, dan lain-lain (Widioatmojo, Sawidji 2015)

Pada prinsipnya, semua perusahaan yang memenuhi persyaratan yang ditetapkan oleh Kepala Eksekutif Pengawas Pasar Modal OJK bisa menerbitkan saham, obligasi dan turunannya kemudian dijual kepada masyarakat. Dengan kata lain, semua perusahaan berpotensi untuk menjadi emiten. Dengan adanya penawaran umum perdana ini, maka emiten yang berhasil go public akan diuntungkan karena selain bisa menjadi besar akibat adanya suntikan modal dari masyarakat juga namanya tentu akan semakin dikenal masyarakat. Bahkan masyarakat yang memiliki saham perusahaan yang bersangkutan bisa menjadi pelanggan yang loyal.

Bagi investor, membeli saham perusahaan yang melakukan penawaran umum memberikan alternatif lain dalam memperoleh penghasilan. Selama ini penghasilan pemilik uang yang paling populer hanya berasal dari bunga tabungan di bank. Dengan membeli saham atau obligasi pemodal akan mendapat penghasilan dari sumber lain, yaitu dividen, capital gain, dan bunga obligasi. Atau dengan kata lain, perusahaan yang go public adalah merupakan penawaran yang bisa dibeli berupa saham, obligasi dan turunannya yang ditawarkan melalui bursa. Hal tersebut merupakan pilihan diantara instrumen investasi lain yang ada, seperti deposito, membeli tanah atau apartemen. Tentu saja sangat 
realistis jika investor membelanjakan uangnya untuk membeli saham jika saham tersebut mampu memberikan penghasilan yang lebih tinggi dari instrumen investasi lain yang diiringi dengan resiko yang terjangkau.

Pertimbangan utama dalam memutuskan untuk membeli atau tidak efek perusahaan yang go public adalah penghasilan yang mungkin didapat dan resiko yang mungkin dihadapi dibanding dengan instrumen investasi lain. Atas dasar ini perusahaan yang ingin go public harus selalu memperhatikan "nasib" investor dengan selalu berusaha untuk meningkatkan nilai perusahaan, sehingga dapat meningkatkan harga saham. Hal ini dikarenakan secara makro ekonomi, perusahaan yang go public merupakan sarana pemerataan pendapatan. Perusahaanperusahaan besar yang mampu menghasilkan keuntungan besar tersebut harus membagi keuntungannya kepada masyarakat luas (pemegang saham). Tentu saja kondisi ini bisa tercapai jika saham yang dijual kepada masyarakat cukup banyak, dan keuntungan yang didistribusikan sebagai dividen juga cukup besar.

\section{Tujuan Initial Public Offering}

Setiap perusahaan yang akan menjual saham kepada masyarakat biasanya memiliki tujuan yang berbeda-beda. Pada umumnya, perusahaan mempunyai tujuan berikut ini: memperbaiki struktur modal, meningkatkan kapasitas produksi, memperluas pemasaran, memperluas hubungan bisnis, dan meningkatkan kualitas manajemen (Samsul, Mohamad. (2006)

1. Memperbaiki Struktur Modal

Bagi perusahaan yang sudah maju, baik dalam bidang produksi maupun penjualan, tetapi struktur modalnya buruk karena memiliki utang yang lebih besar daripada modal sendiri, maka perusahaan itu dapat menawarkan saham kepada masyarakat luas. Hasil emisinya akan digunakan untuk membayar sebagian besar utang sehingga akan menghemat beban bunga pinjaman. Lebih lanjut, struktur modal akan menjadi lebih baik dan laba perusahaan akan meningkat.

2. Meningkatkan Kapasitas Produksi

Bagi perusahaan yang kewalahan melayani order penjualan karena produksi terbatas, maka terbuka kesempatan untuk mencari tambahan modal melalui pasar modal. Perusahaan yang sedang berada dalam kondisi seperti ini sahamnya sangat diminati oleh investor, karena di mata investor hasil emisi akan digunakan untuk hal yang produktif. Bagi perusahaan, tindakan emisi saham lebih menguntungkan daripada mengambil kredit jangka panjang yang haru menanggung beban bunga. Hasil emisi juga dapat digunakan untuk membeli tanah atau mesin produksi dan sebagai modal kerja. Bagi perusahaan yang ingin mengembangkan jenis produk baru, inovasi produk yang menurut hasil 
analisis pasar berprospek bagus dapat dibiayai oleh modal saham hasil emisi baru. Emisi yang ditujukan untuk mengembangkan produk baru sangat diminati oleh investor karena perusahaan dianggap berada dalam posisi "growth company", yang dalam jangka panjang akan meningkatkan harga saham di pasar. Saham perusahaan semacam ini sering disebut "growth stock" yang memiliki harga pasar tinggi.

3. Memperluas Pemasaran

Perusahaan yang memiliki kapasaitas produksi berlebihan dan penjualan yang lancar karena banyak peminatnya tetapi belum tergarap dengan baik, pasti membutuhkan tambahan modal untuk memperluas daerah pemasaran, memperluas jaringan pemasaran, memperbanyak agen penjual, atau meningkatkan penjualan kredit dan meningkatkan masa pembayaran kredit.

4.Memperluas Hubungan Bisnis

Bagi perusahaan yang sudah maju dan sudah besar tetapi masih ingin lebih maju lagi, atau ingin lebih besar lagi, maka emisi saham merupakan sarana yang tepat. Nama perusahaan yang masuk pasar modal selalu diberitakan setiap hari melalui televisi, radio, dan media cetak lainnya sehingga menjadi terkenal. Perusahaan yang berhasil dengan baik akan memiliki nama baik yang tersebar di seluruh dunia. Apabila suatu ketika perusahaan ingin mencari tambahan modal, maka dengan mudah dapat memperolehnya melalui pasar modal.

Selain itu, perusahaan yang sudah go public lebih mudah mengembangkan perusahaan melalui merger, konsolidasi, akuisisi, ataupun aliansi, apalagi harga saham perusahaan bersangkutan di pasar dapat dipertahankan atau selalu meningkat. Emiten dapat menjaga harga saham di pasar tetap berada dalam posisi yang baik apabila mampu menjaga kinerja keuangan secara terus menerus. Kinerja keuangan yang baik secara terus menerus dapat dicapai oleh manajemen yang profesional. 5.Meningkatkan Kualitas Manajemen

Keuntungan lain dari go public adalah meningkatnya kualitas manajemen. Peningkatan kualitas manajemen ini berasal dari dorongan pihak Bapepam (sekarang OJK, penulis) dan Bursa Efek atau peraturan perundangan yang mewajibkan emiten untuk melakukan good corporate governance, keterbukaan informasi (transparency), dan larangan melakukan tindakan yang bersifat conflict of interest. Emiten atau perusahaan publik atau perusahaan go public atau issuer merupakan istilah yang memiliki makna yang sama.

\section{Mekanisme Go Public.}

Pusat informasi go public Bursa Efek Indonesia menerangkan adanya 5 (lima) tahapan yang harus dilakukan agar suatu perusahaan dapat menjadi Perusahaan Terbuka, yaitu (IDX, 2016): 
1.Penunjukan Underwriter dan Persiapan Dokumen

Pada tahap awal, perusahaan perlu membentuk tim internal, menunjuk underwriter dan lembaga serta profesi penunjang pasar modal yang akan membantu perusahaan melakukan persiapan go public, meminta persetujuan RUPS dan merubah Anggaran Dasar, serta mempersiapkan dokumen-dokumen yang diperlukan untuk disampaikan kepada Bursa Efek Indonesia dan OJK.

2. Penyampaian Permohonan Pencatatan Saham ke Bursa Efek Indonesia

Untuk menjadi perusahaan publik yang sahamnya dicatatkan dan diperdagangkan di Bursa Efek Indonesia, perusahaan perlu mengajukan permohonan untuk mencatatkan saham, dilengkapi dengan dokumen-dokumen yang dipersyaratkan, antara lain profil perusahaan, laporan keuangan, opini hukum, proyeksi keuangan, dan lain-lain. Perusahaan juga perlu menyampaikan permohonan pendaftaran saham untuk dititipkan secara kolektif (scripless) di Kustodian Sentral Efek Indonesia (KSEI). Bursa Efek Indonesia akan melakukan penelaahan atas permohonan yang diajukan perusahaan dan akan mengundang perusahaan beserta underwriter dan profesi penunjang untuk mempresentasikan profil perusahaan, rencana bisnis dan rencana penawaran umum yang akan dilakukan.

Untuk mengetahui lebih lanjut tentang kegiatan usaha perusahaan, Bursa Efek Indonesia juga akan melakukan kunjungan ke perusahaan serta meminta penjelasan lainnya yang relevan dengan rencana IPO perusahaan. Apabila perusahaan telah memenuhi persyaratan yang ditentukan, dalam waktu maksimal 10 Hari Bursa setelah dokumen lengkap, Bursa Efek Indonesia akan memberikan persetujuan prinsip berupa Perjanjian Pendahuluan Pencatatan Saham kepada perusahaan.

3. Penyampaian Pernyataan Pendaftaran ke OJK

Setelah mendapatkan Perjanjian Pendahuluan Pencatatan Saham dari Bursa Efek Indonesia, perusahaan menyampaikan Pernyataan Pendaftaran dan dokumen pendukungnya kepada OJK untuk melakukan penawaran umum saham. Dokumen pendukung yang diperlukan antara lain adalah prospektus. Dalam melakukan penelaahan, OJK dapat meminta perubahan atau tambahan informasi kepada perusahaan untuk memastikan bahwa semua fakta material tentang penawaran saham, kondisi keuangan dan kegiatan usaha perusahaan diungkapkan kepada publik melalui prospektus. Sebelum mempublikasikan prospektus ringkas di surat kabar atau melakukan penawaran awal (bookbuilding), perusahaan harus menunggu ijin dari OJK. Perusahaan juga dapat melakukan public expose jika ijin publikasi telah dikeluarkan OJK. OJK akan memberikan pernyataan efektif setelah perusahaan menyampaikan informasi mengenai harga penawaran umum saham dan keterbukaan informasi lainnya. Apabila Pernyataan 
Pendaftaran perusahaan telah dinyatakan efektif oleh OJK, perusahaan mempublikasikan perbaikan/tambahan informasi prospektus ringkas di surat kabar serta menyediakan prospektus bagi publik atau calon pembeli saham, serta melakukan penawaran umum.

4.Penawaran Umum Saham kepada Publik

Masa penawaran umum saham kepada publik dapat dilakukan selama 1-5 hari kerja. Dalam hal permintaan saham dari investor melebihi jumlah saham yang ditawarkan (over-subscribe), maka perlu dilakukan penjatahan. Uang pesanan investor yang pesanan sahamnya tidak dipenuhi harus dikembalikan (refund) kepada investor setelah penjatahan. Distribusi saham akan dilakukan kepada investor pembeli saham secara elektronik melalui KSEI (tidak dalam bentuk sertifikat).

5.Pencatatan dan Perdagangan Saham di Bursa Efek Indonesia

Perusahaan menyampaikan permohonan pencatatan saham kepada Bursa disertai dengan bukti surat bahwa Pernyataan Pendaftaran telah dinyatakan efektif oleh OJK, dokumen prospektus, dan laporan komposisi pemegang saham perusahaan. Bursa Efek Indonesia akan memberikan persetujuan dan mengumumkan pencatatan saham perusahaan dan kode saham (ticker code) perusahaan untuk keperluan perdagangan saham di Bursa. Kode saham ini akan dikenal investor secara luas dalam melakukan transaksi saham perusahaan di Bursa Efek Indonesia. Setelah saham tercatat di Bursa, investor akan dapat memperjualbelikan saham perusahaan kepada investor lain melaui broker atau Perusahaan Efek yang menjadi Anggota Bursa terdaftar di Bursa Efek Indonesia.

\section{METODE PENELITIAN}

Pendekatan yang digunakan dalam penelitian ini adalah pendekatan kualitatif. Metode yang digunakan adalah normatif deskriptif yang menganalisa hukum normatifitas hukum yang disajikan secara deskriptif dan dihubungkan dengan potret perusahaan rintisan yang sedang berkemabnagn dalam menerbitkan IPO. Benchmark juga dilakukan dengan berusaha uamum dan perusahaan startup lainnya. Sumber data dalam penelitian ini adalah data sekunder.

\section{PEMBAHASAN}

\section{Sekilas Mengenai PT Aplikasi Karya Anak Bangsa (Go-Jek)}

PT Aplikasi Karya Anak Bangsa didirikan pada tahun 2010 di Jakarta oleh Nadiem Makarim sebagai layanan angkutan sepeda motor berbasis Ponsel Pintar dengan nama "Go-Jek". Go-Jek sendiri akhirnya telah berkembang menjadi platform mobile on-demand dan aplikasi yang menyediakan berbagai layanan yang mencakup tidak hanya transportasi dan logistik, namun juga pembayaran mobile, pengiriman makanan, dan 
banyak layanan on-demand lainnya. 3 (tiga) nilai penting dari usaha Go-Jek ini adalah kecepatan, inovasi, dan dampak sosial.

Jika dilihat dari bentuknya, PT Aplikasi Karya Anak Bangsa merupakan Perseroan Terbatas (PT) karena PT Aplikasi Karya Anak Bangsa termasuk dalam badan hukum dan PT Aplikasi Karya Anak Bangsa juga menggunakan pedoman Good Corporate Governance (GCG) agar menjadi acuan bagi anggota Direksi dan anggota Dewan Komisaris dalam menjalankan perusahaan agar senantiasa memperhatikan perundang-undangan, anggaran dasar Perseroan. Efektifitas merupakan derajat keberhasilan sebuah Perusahaan sampai suatu perusahaan dinyatakan berhasil. Efektifitas PT Aplikasi Karya Anak Bangsa sebagai penentu derajat dapat di lihat dari beberapa penghargaan yang diterima oleh PT Aplikasi Karya Anak Bangsa, diantaranya PT Aplikasi Karya Anak Bangsa (Go-Jek) menempati peringkat ke-17, bersama sejumlah perusahaan-perusahaan kelas dunia lainnya seperti Apple, Unilever, Microsoft, dan masih banyak lagi. PT Aplikasi Karya Anak Bangsa (Go-Jek) menjadi satu-satunya perusahaan asal Asia Tenggara yang masuk dalam daftar tersebut.

Selain itu PT Aplikasi Karya Anak Bangsa meraih penghargaan sebagai Top 10 Most Brand in Indonesia pada acara Brand Asia 2017, serta mendapatkan penghargaan dala Bank Indonesia Awards sebagai Perusahaan Fintech Teraktif Pendukug Gerakan Nasional Non Tunai (GNNT) Inklusi dan Edukasi Keuangan serta Pemberdayaan UMKM1, serta mendapatkan penghargaan Most Innovative Apps pada Kategori Operator dalam ajang Indonesia Golden Ring Awards 2015. (Detik, 2017)

\section{Persyaratan IPO di Indonesia}

Perusahaan dapat mencatatkan sahamnya di Papan Utama atau Papan Pengembangan. Persyaratan untuk dapat mencatatkan saham di Bursa Efek Indonesia di Papan Utama dan Papan Pengembangan adalah sebagai berikut:

Tabel Persyaratan Listing di Papan Utama dan Papan

Pengembangan pada Bursa Efek Indonesia

\section{Papan utama} Papan Pengembangan

Badan Hukum berbentuk Perseroan Terbatas (PT) yang memiliki:

- Komisaris Independen minimal 30\% dari jajaran Dewan Komisaris;

- Direktur Independen minimal 1 orang dari jajaran anggota Direksi;

- Komite Audit;

- Unit Audit Internal;

- Sekretaris Perusahaan

Operasional pada core business yang Operasional pada core business yang
sama $>36$ bulan sama $>12$ bulan

${ }^{1}$ Awards (n.d.). Diakses tanggal 10 Maret 2017 jam 23.10. www.gojek.com, 


\begin{tabular}{|c|c|}
\hline $\begin{array}{l}\text { Membukukan laba usaha pada } 1 \text { tahun } \\
\text { buku terakhir }\end{array}$ & $\begin{array}{l}\text { Tidak harus membukukan laba, namun } \\
\text { jika belum membukukan keuntungan, } \\
\text { berdasarkan proyeksi keuangan pada } \\
\text { akhir tahun ke-2 telah memperoleh laba } \\
\text { (khusus sektor tertentu : pada akhir } \\
\text { tahun ke-6) }\end{array}$ \\
\hline Laporan Keuangan Auditan $>3$ tahun & Laporan Keuangan Auditan >12 Bulan \\
\hline $\begin{array}{l}\text { Opini Laporan Keuangan: Wajar Tanpa } \\
\text { Pengecualian ( } 2 \text { tahun terakhir) }\end{array}$ & $\begin{array}{l}\text { Opini Laporan Keuangan: Wajar Tanpa } \\
\text { Pengeceualian }\end{array}$ \\
\hline Aset Berwujud Bersih > Rp100 miliar & Aset Berwujud Bersih >Rp5 miliar \\
\hline $\begin{array}{l}\text { Saham yang ditawarkan kepada publik*): } \\
\text { Min. } 300 \text { juta saham } \\
20 \% \text { dari total saham, untuk ekuitas < Rp500 } \\
\text { miliar } \\
15 \% \text { dari total saham, untuk ekuitas Rp500 } \\
\text { miliar - Rp2 triliun } \\
\text { 10\% dari total saham, untuk ekuitas > Rp2 } \\
\text { triliun } \\
\quad \text { *)Termasuk yang dimiliki publik } \\
\text { sebelum perusahaan go-public }\end{array}$ & $\begin{array}{l}\text { Saham yang ditawarkan kepada } \\
\text { publik*): } \\
\text { Min. } 150 \text { juta saham } \\
20 \% \text { dari total saham, untuk ekuitas < } \\
\text { Rp500 miliar } \\
15 \% \text { dari total saham, untuk ekuitas } \\
\text { Rp500 miliar - Rp2 triliun } \\
\text { 10\% dari total saham, untuk ekuitas > } \\
\text { Rp2 triliun } \\
\text { *)Termasuk yang dimiliki publik } \\
\text { sebelum perusahaan go-public }\end{array}$ \\
\hline Jumlah Pemegang Saham > 1000 pihak & Jumlah Pemegang Saham > 500 pihak \\
\hline
\end{tabular}

Go-Jek sebagai perusahaan rintisan akan mencatat sahamnya di Papan Pengembangan, sehingga persyaratan yang harus diikuti tidak seberat pada papan utama. Hambatan yang mungkin dihadapi oleh GoJek ketika akan melakukan penawaran umum perdana kemungkinan disebabkan oleh statusnya yang dianggap masih menjadi perusahaan "muda" dengan financial history yang masih dibangun. Selain itu, persyaratan mengenai laba juga masih menjadi hambatan Go-Jek untuk dapat melakukan IPO. Adanya persyaratan pembukuan laba untuk dapat melakukan IPO hanya terdapat pada perusahaan yang akan mencatatkan saham di bursa pada Papan Utama. Go-Jek dapat mencatatkan saham pada Papan Pengembangan apabila terkendala pada pembukuan laba, akan tetapi hambatan berikutnya apabila Go-Jek mencatatkan pada Papan Pengembangan adalah bahwa Go-Jek harus memiliki proyeksi keuntungan jangka panjang untuk beberapa tahun kedepan sehingga dapat memberikan daya tarik bagi para investor untuk dapat menanamkan modalnya kepada Go-Jek.

\section{Regulasi yang dapat menghambat PT Aplikasi Karya Anak Bangsa (Go- Jek) melakukan IPO}

Go-Jek merupakan perusahaan rintisan (startup) berbasis online yang menyediakan berbagai jasa, salah satunya adalah jasa transportasi online. Dalam dunia startup dikenal beberapa istilah yang menjabarkan 
besaran perusahaan rintisan yang didirikan (Kontan, 2017). Berikut beberapa istilah yang dikenal:

1.Cockroach. dalam dunia startup adalah sebutan untuk perusahaan rintisan awal dengan valuasi masih kecil, tetapi tahan banting. Perusahaan yang masih dalam level ini dapat menarik investor untuk mengikutsertakan modalnya sehingga valuasinya membesar.

2.Ponies. Istilah ini adalah untuk menjuluki perusahaan-perusahaan rintisan dengan valuasi menembus US\$10 juta atau sekitar Rp 130 miliar. Apabila perusahaan di level ini dapat mempertahankan dan menaikkan nilai valuasinya, maka para calon investor dengan modal yang lebih besar akan tertarik menginjeksi dana segar dan valuasi perusahaan tersebut akan menuju ke level berikutnya.

3.Centaurs, merupakan istilah untuk perusahaan rintisan dengan valuasi yang sudah melebihi angka US\$ 100 juta atau setara dengan Rp 1,35 triliun. Apabila perusahaan rintisan yang sudah sampai pada level ini masih dapat meningkatkan valuasinya, maka para calon investor dengan dana yang besar akan tertarik untuk mengikutsertakan modalnya pada perusahaan ini, sehingga semakin mendorong valuasi perusahaan.

4.Unicorn adalah istilah untuk kuda bertanduk yang ditunggangi para dewa di dalam Mitologi Yunani. Di dalam dunia startup, unicorn adalah sebutan untuk perusahaan rintisan yang valuasinya sudah menembus US\$ 1 miliar atau setara dengan Rp 13,5 triliun.

Dengan berbagai istilah yang sudah dijelaskan di atas, Go-Jek adalah perusahaan rintisan yang sudah mencapai level unicorn. Pada kebiasaannya, perusahaan startup yang sudah sampai level unicorn tentu akan semakin sulit untuk mendapatkan dana segar dari investor, tetapi bukan karena perusahaan tersebut sudah tidak menarik melainkan sudah tidak terlalu banyak lagi investor yang memiliki kapasitas dana hingga sebesar itu. Oleh sebab itu untuk perusahaan rintisan yang sudah mencapai level ini, menawarkan saham kepada publik menjadi jalur yang paling memungkinkan untuk dapat memperbesar aset perusahaan dan menaikkan valuasinya.

\section{Perbandingan Perusahaan Rintisan (startup) PT Aplikasi Karya Anak Bangsa (Go-Jek) Dengan Perusahaan Lain Dalam Hal Pelaksanaan Mekanisme Penawaran Umum Perdana (IPO) di Indonesia}

1. Pelaksanaan IPO oleh Perusahaan Biasa (PT Jasa Armada Indonesia, Tbk - Anak Perusahaan PT Pelabuhan Indonesia II (Persero)

Sebagai bahan perbandingan, akan dijelaskan proses IPO yang dilakukan anak usaha PT Pelabuhan Indonesia II (Persero)/IPC, PT Jasa Armada Indonesia, Tbk (JAI). Tanggal 22 Desember 2017 JAI telah resmi mencatatkan sahamnya di Bursa Efek Indonesia (BEI). Perusahaan yang 
tercatat dengan kode saham "IPCM" ini telah melepas sejumlah 1,21 miliar lembar saham baru atau setara dengan 20\% dari modal ditempatkan dan disetor. PT Jasa Armada Indonesia Tbk resmi menjadi emiten ke-35 yang mencatatkan sahamnya di BEI pada tahun 2017.

Setelah masa penawaran yang berlangsung pada tanggal 18-19 Desember 2017, harga IPO saham JAI ditetapkan sebesar Rp 380 per lembar saham, sehingga JAI akan memperoleh dana sekitar Rp 461,89 miliar dari hasil IPO ini. Saham JAI juga mengalami kelebihan permintaan (oversubscribed) saat proses penawaran awal (bookbuilding) sebanyak dua kali. Perseroan menunjuk PT Danareksa Sekuritas dan PT Mandiri Sekuritas sebagai penjamin pelaksana emisi efek (join lead underwriters/JLU). Sedangkan PT RHB Sekuritas Indonesia sebagai penjamin emisi (underwriter). JAI juga mengalokasikan sebanyakbanyaknya sebesar $10 \%$ untuk karyawan melalui program Employee Stock Allocation (ESA).

Perseroan berencana untuk menggunakan 90\% dan hasil IPO untuk membiayai belanja modal (capital expenditure/capex), sisanya 10\% untuk modal operasional kerja (working capital). Perseroan berencana menambah armada untuk segmen bisnis ship to ship (STS), jalur kanal, dan pelabuhan swasta. Selain untuk keperluan ekspansi, IPO juga akan membuat JAI lebih profesional dan transparan. JAI merupakan perusahaan jasa pemanduan dan penundaan kapal terbesar di Indonesia. Saat ini, IPC menguasai 99,86\% saham JAI, sedangkan PT Multi Terminal Indonesia memiliki $0,14 \%$ saham. JAI merupakan perusahaan pemanduan dan penundaan kapal dengan tingkat profitabilitas paling tinggi. Dalam tiga tahun terakhir, rata-rata margin laba bersih sebesar 19,4\% (IPC, 2017).

Sebagai anak perusahaan dari PT Pelabuhan Indonesia II (Persero), kegiatan usaha utama PT Jasa Armada Indonesia Tbk adalah di bidang usaha jasa penyelenggaraan dan pengusahaan jasa kapal, penumpang, barang dan kegiatan jasa terkait dengan kepelabuhanan. PT Jasa Armada Indonesia Tbk berkedudukan di Jakarta, Indonesia, dengan lokasi kantor dan pelabuhan yang dibawahinya termasuk Unit Operasi Tanjung Priok, Banten, Panjang, Palembang, Teluk Bayur, Bengkulu, Pontianak, Cirebon, Jambi, Pangkal Balam, Tanjung Pandan.

Terkait dengan saham perdana yang ditawarkan, PT Jasa Armada Indonesia Tbk mengeluarkan sebanyak-banyaknya 1.743.987.600 saham biasa atas nama yang seluruhnya adalah saham baru dan dikeluarkan dari portepel Perseroan, dengan nilai nominal Rp 100,- setiap saham, yang mewakili sebesar 30\% dari modal ditempatkan dan disetor Perseroan setelah Penawaran Umum Perdana Saham (“Saham yang Ditawarkan”). Penawaran saham perdana PT Jasa Armada Indonesia Tbk dijamin oleh PT Danareksa Sekuritas dan PT Mandiri Sekuritas selaku Penjamin Pelaksana Emisi Efek dan oleh PT RHB Sekuritas Indonesia selaku 
Penjamin Emisi Efek yang menjamin dengan kesanggupan penuh (full commitment) terhadap sisa Saham Yang Ditawarkan yang tidak dipesan dalam Penawaran Umum Perdana Saham Perseroan. Penentuan harga saham oleh tiap perusahaan yang melakukan proses go public pada umumnya ditawarkan dibawah harga pasar, dengan menjanjikan investor dengan keuntungan yang dapat diukur dari selisih antara harga yang ditawarkan dengan harga saham tertinggi pada awal penawaran (Media Indonesia, 2017).

2.Pelaksanaan IPO oleh Perusahaan Rintisan (PT Kioson Indonesia, Tbk.

PT Kioson Komersial Indonesia Tbk berdiri pada tanggal 29 Juni 2015 dan mulai beroperasi komersial pada bulan Agustus 2015. Kantor pusat PT Kioson Komersial Indonesia Tbk berlokasi di AXA Tower Lt. 42, Kuningan City, Jl. Prof. Dr. Satrio kav. 18 Kuningan, Jakarta Selatan 12940, Indonesia. Susunan pemegang saham yang memiliki 5\% atau lebih saham PT Kioson Komersial Indonesia Tbk, yaitu: PT Artav Mobile Indonesia $(53,89 \%)$, PT Seluler Makmur Sejahtera $(9,62 \%)$ dan PT Sinar Mitra Investama $(9,62 \%)$.

Berdasarkan Anggaran Dasar Perusahaan, ruang lingkup kegiatan KIOS adalah menjalankan usaha dalam bidang perdagangan, jasa, pembangunan, percetakan, perindustrian, angkutan, perbengkelan dan pertanian. Saat ini, kegiatan utama Kioson adalah bidang perdagangan online atau e-commerce, dimana Kioson merupakan sebuah perusahaan teknologi yang menyediakan perangkat lunak dan perangkat keras platform untuk membantu Usaha, Mikro, Kecil dan Menengah (UMKM) di Indonesia melalui sistem kemitraan yang disebut Kioson Cash Point, dimana dalam melakukan kegiatan perekrutan mitra bisnis dan/atau pengumpulan hasil transaksi dari mitra bisnis Perusahaan bekerjasama dengan pihak ketiga, yang disebut Kioson Corporate Corespondence.

Pada tanggal 25 September 2017, KIOS memperoleh pernyataan efektif dari Otoritas Jasa Keuangan (OJK) untuk melakukan Penawaran Umum Perdana Saham KIOS (IPO) kepada masyarakat sebanyak 150.000.000 saham dengan nilai nominal Rp100,- per saham dengan harga penawaran Rp300,- per saham disertai dengan Waran Seri I sebanyak 150.000.000 dengan harga pelaksanaan Rp375,- per saham. Saham dan waran tersebut dicatatkan pada Bursa Efek Indonesia (BEI) pada tanggal 05 Oktober 2017 (Britama, 2017). Sehubungan dengan Penawaran Umum Perdana Saham Perseroan PT Kioson Komersial Indonesia, PT Sinarmas Sekuritas berkedudukan sebagai Penjamin Pelaksana Emisi Efek sekaligus Penjamin Emisi Efek.

Dalam rangka penawaran saham perdana, perseroan telah menyampaikan Pernyataan Pendaftaran Penawaran Umum Perdana Saham kepada Otoritas Jasa Keuangan ("OJK") di Jakarta pada tanggal 2 
Agustus 2017 dengan surat No. 067/KIOSONEX/VIII/2017, sesuai dengan persyaratan yang ditetapkan dalam Undang-Undang No. 8 Tahun 1995 tanggal 10 November 1995 tentang Pasar Modal, Lembaran Negara Republik Indonesia No. 64 Tahun 1995, Tambahan No. 3608 beserta peraturan-peraturan pelaksanaannya (“UUPM").

Pada awalnya perseroan merencanakan akan mencatatkan sahamsaham yang ditawarkan dalam Penawaran Umum Perdana ini pada PT Bursa Efek Indonesia ("BEI") sesuai dengan Perjanjian Pendahuluan Pencatatan Efek tanggal 31 Agustus 2017 yang telah dibuat antara Perseroan dengan BEI. Hal ini dikarenakan apabila syarat-syarat pencatatan Saham di BEI tidak terpenuhi, maka Penawaran Umum batal demi hukum dan pembayaran pesanan Saham tersebut wajib dikembalikan kepada para pemesan sesuai ketentuan-ketentuan dalam Perjanjian Penjaminan Emisi Efek dan dan Peraturan No. IX.A.2, Lampiran Keputusan Ketua Bapepam dan LK No. Kep-122/BL/2009 tanggal 29 Mei 2009. Kioson, 2017)

\section{SIMPULAN}

Beberapa hambatan yang dihadapi oleh perusahaan rintisan untuk melakukan IPO di Indonesia, diantaranya yaitu terkait dengan financial history yang dianggap masih "muda", adanya persyaratan mengenai laba yang belum bisa dipenuhi oleh perusahaan rintisan, peletakan posisi papan yang berada di papan pengembangan yang tentu semakin mengurangi daya tarik investor menanamkan modalnya di perusahaan rintisan, serta belum dimilikinya proyeksi keuntungan jangka panjang. Manfaat IPO yang bisa dirasakan oleh perusahaan yang melakukan proses go public diantaranya adalah: (1) Memperbaiki Struktur Modal, (2) Meningkatkan Kapasitas Produksi, (3) Memperluas Pemasaran, (4) Memperluas Hubungan Bisnis, dan (5) Meningkatkan Kualitas Manajemen.

Mekanisme pelaksanaan IPO oleh perusahaan biasa dan perusahaan rintisan di Indonesia masih didasarkan pada aturan yang sama, yakni UU Pasar Modal dan peraturan-peraturan terkait. Hal inilah yang masih menjadi hambatan bagi perusahaan rintisan untuk memulai perdagangan saham di bursa efek karena banyak hal yang harus dipertimbangkan yang kemungkinan besar justru dapat menghambat perkembangan perusahaan itu sendiri.

\section{DAFTAR PUSTAKA}

Anak Usaha IPC Resmi Catatkan Saham Di Bursa Efek Indonesia. Media Release IPC tanggal 22 Desember 2017.

Baker, Malcolm \& Gompers, Paul A. (2003), The Determinants of Board Structure at the Initial Public Offering. The Journal of Law \& 
Economics, The University of Chicago Law School, Vol. 46, No. 2, October.

Banyak Jalan Danai Startup. (Edisi 04, Oktober 2016). Buletin APJII.

Bill, Arthur H. (1993). On Your Mark, Get Set...: Positioning a Company for a Future Initial Public Offering. Business Law Today, Vol.2, No.3, January/February.

Curhat Go-Jek Soal Kakunya Aturan IPO di Indonesia (n.d.). Diakses tanggal 5 Maret 2018 jam 19:45.

http:/ / tekno.liputan6.com/read/3280549/curhat-go-jek-soal-kakunyaaturan-ipo-di-indonesia

Draho, Jason. (2004). The IPO Decision: Why and How Companies Go Public. Cheltenham, UK: Edward Elgar Publishing.

Fakhruddin, Hendy M. (2008). Go Public: Strategi Pendanaan dan Peningkatan Nilai Perusahaan. Jakarta: PT Elex Media Komputindo.

Fielnanda, Refky. "Konsep Screening Saham Syariah di Indonesia." ALFALAH: Journal of Islamic Economics 2.2 (2017).

Go-Jek Bakal IPO di Indonesia (n.d.). Diakses tanggal 5 Maret 2018 jam 19:30. http:/ / bisnis.liputan6.com/read/3344435/go-jek-bakal-ipo-diindonesia

Hauser, Shmuel; Yaari, Uzi; Tanchuma, Yael \& Baker, Harold (2006). Initial Public Offering Discount and Competition. The Journal of Law \& Economics, The University of Chicago Law School, Vol.49, No.1, April.

Initial Public Offering (IPO) (n.d.). Diakses tanggal 6 Maret 2018 jam 13:14. http:/ / e-journal.uajy.ac.id/658/3/2EM16706.pdf

Jalan Panjang Startup Menjadi Unicorn (n.d.). Diakses tanggal 5 Maret 2018 jam 19:00.

http:/ /lipsus.kontan.co.id/v2/startup/

Kim Juseong (1999). The Relaxation of Financing Constraints by the Initial Public Offering of Small Manufacturing Firms. Small Business Economics, Vol.12, No.3, May.

Pencatatan Perdana Saham PT Kioson Komersial Indonesia Tbk (n.d.). Diakses tanggal 16 Maret 2018 jam 15:33.

http:/ /yuknabungsaham.idx.co.id/post/IPO-PT-Kioson-KomersialIndonesia-Tbk

Pengertian Perusahaan Go Public (n.d.). Diakses tanggal 6 Maret 2018 jam 13:00.

https:/ / www.scribd.com/ document/346218906/Pengertian-PerusahaanGo-Public

Proses Go Public (Go Public Process) (n.d.). Diakses tanggal 6 Maret 2018 jam 15:00. https://gopublic.idx.co.id/2016/06/22/.proses-go-public/

Prospektus PT Kioson Komersial Indonesia, Tbk (n.d.). Diakses tanggal 16 Maret 2018 jam 15:41. 
https://www.kioson.com/wp-content/uploads/2018/01/bukuprospektus-kioson-lowress.pdf

Prospektus Ringkas PT Jasa Armada Indonesia Tbk. (2017, November 27). Media Indonesia.

Samsul, Mohamad. (2006). Pasar Modal \& Manajemen Portfolio. Jakarta: Erlangga.

Sejarah dan Profil Singkat KIOS (Kioson Komersial Indonesia Tbk) (n.d.). diakses tanggal 27 Maret 2018 jam 11:55.

http:/ / britama.com/index.php/2017/10/sejarah-dan-profil-singkat-kios/ Unicorn (n.d.). Diakses tanggal 5 Maret 2018 jam 19:30. https://en.wikipedia.org/wiki/Unicorn

Undang-Undang Nomor 8 Tahun 1995 Tentang Pasar Modal (Lembaran Negara Tahun 1995 Nomor 64, Tambahan Lembaran Negara Nomor 3608).

Undang-Undang Nomor 40 Tahun 2007 Tentang Perseroan Terbatas (Lembaran Negara Tahun 1995 Nomor 13, Tambahan Lembaran Negara Nomor 3587).

Widioatmojo, Sawidji. (2015). Pengetahuan Pasar Modal Untuk Konteks Indonesia. Jakarta: Elex Media Komputindo. 